Distribution of Ordinary High Water Mark (OHWM) Indicators and Their Reliability in Identifying the Limits of "Waters of the United States" in Arid Southwestern Channels

Robert W. Lichvar, David C. Finnegan,

February 2006

Michael P. Ericsson, and Walter Ochs

US Army Corps of Engineers ${ }_{\circledast}$

Engineer Research and Development Center 


\section{Distribution of Ordinary High Water Mark (OHWM) Indicators and Their Reliability in Identifying the Limits of "Waters of the United States" in Arid Southwestern Channels}

ROBERT W. LICHVAR, DAVID C. FINNEGAN, MICHAEL P. ERICSSON, AND WALTER OCHS

U.S. Army Engineer Research and Development Center

Cold Regions Research and Engineering Laboratory

72 Lyme Road

Hanover, New Hampshire 03755

Approved for public release; distribution is unlimited.

Prepared for U.S. Army Corps of Engineers

Washington, DC 20314-1000 


\section{ABSTRACT}

The U.S. Army Corps of Engineers (COE) is actively involved in floodplain management and regulation of dry wash floodplains in the western United States. The COE also regulates "Waters of the United States" (WoUS) under Sec. 404 of the Clean Water Act by determining the extent of surface indicators related to "ordinary" flood discharges known as Ordinary High Water Marks (OHWM). The return interval for inundation to the WoUS boundary is not well understood in the arid West. COE hydrologic models require detailed site information for rainfall and stream flow characteristics, as well as on-site surveys to determine channel morphology, width, fluvial patterns, slope, and other physical attributes. The focus of this research is to quantitatively correlate field indicators to flood return inundation levels in support of identifying the events that best represent the extent of the "ordinary" high water using high-resolution topography acquired through Light Detection and Ranging (LiDAR). The NASA's Airborne Topographic Mapper (ATM) was the source of high-resolution topographic data for several stream reaches throughout the Mojave Desert, California. This research showed that field indicators commonly used to delineate the extent of the OHW are distributed across the entire floodplain and are not associated with a particular level of event. However, a consistent pattern of geomorphic signature and vegetation density is highly correlated to moderate flood events. A hypothesis and a working model were developed to explain the distribution pattern of various OHWM indicators and the repeating geomorphic signature.

DISCLAIMER: The contents of this report are not to be used for advertising, publication, or promotional purposes. Citation of trade names does not constitute an official endorsement or approval of the use of such commercial products. All product names and trademarks cited are the property of their respective owners. The findings of this report are not to be construed as an official Department of the Army position unless so designated by other authorized documents. 


\section{CONTENTS}

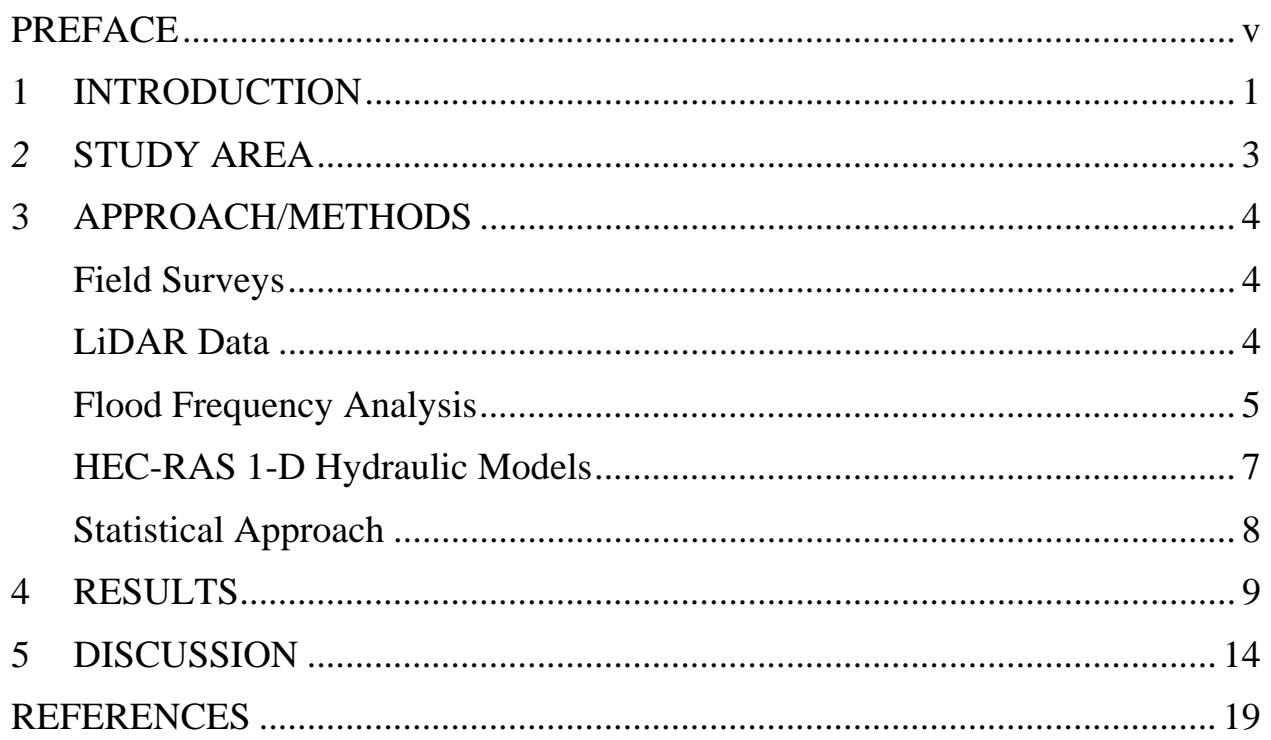

\section{ILLUSTRATIONS}

Figure 1. Location of the Mission Creek study site ............................................. 3

Figure 2. Aircraft and equipment used in acquisition of the LiDAR data ............ 5

Figure 3. ATM-III LiDAR-derived Digital Elevation Model for Mission Creek, southern California ...................................................... 6

Figure 4. Estimated frequency of maximum annual discharges at the Mission Creek Gage ............................................................................ 7

Figure 5. Typical arid southwestern stream cross section and its associated hydrogeomorphic floodplain units ................................................... 9

Figure 6. Select HEC-RAS modeling results for 5-, 10-, and 25-year calculated return interval discharges at Mission Creek 10

Figure 7. Field mapping results at Mission Creek for hydrogeomorphic positions and OHWM indicators, percent vegetation cover, and composite geomorphic textures

Figure 8. Vegetation and cobble textures correlated to flood return intervals and mapped polygon areas

Figure 9. OHWM indicators collected at Mission Creek and their distribution within the flood return intervals 13

Figure 10. Observed flood hydrograph for Mission Creek 15 
Figure 11. Working OHW concept model for understanding the distribution of OHWM indicators

Figure 11. Aerial photography and field-derived channel boundaries showing the active floodplain identified by the reduced vegetation cover and sandy to cobble textures

\section{TABLE}

Table 1. OHWM indicators, Mission Creek 2003 


\section{PREFACE}

This report was prepared by Robert W. Lichvar, David C. Finnegan, Michael P. Ericsson, and Walter Ochs, all of the Remote Sensing/Geographical Information Systems and Water Resources Branch (RS/GIS), Cold Regions Research and Engineering Laboratory (CRREL), Engineer Research and Development Center (ERDC), Hanover, New Hampshire.

This research was supported by on-going funding from the Wetlands Regulatory Assistance Program (WRAP), Headquarters, U.S. Army Corps of Engineers. Special thanks is extended to the Dr. William Krabill and his team at the Airborne Topographic Mapper group at NASA Goddard Space Flight Center for their collaboration and for providing LiDAR support for this study. The authors thank The Wildlands Conservancy, Mission Creek Preserve for allowing access to the Mission Creek study area and other logistic support. Also, they thank Dr. Steven Daly and Dr. David Goldman, ERDC/CRREL, for their critical input and assistance in running and interpreting HEC-RAS and other statistical hydrologic output data.

This report was prepared under the general supervision of Timothy Pangburn, Chief, RS/GIS Branch; Dr. Lance Hansen, Deputy Director; and James L. Wuebben, Acting Director, CRREL.

The Commander and Executive Director of the Engineering Research and Development Center is COL James R. Rowan. The Director is Dr. James R. Houston. 


\title{
Distribution of Ordinary High Water Mark (OHWM) Indicators and Their Reliability in Identifying the Limits of "Waters of the United States" in Arid Southwestern Channels
}

\author{
ROBERT W. LICHVAR, DAVID C. FINNEGAN, \\ MICHAEL P. ERICSSON, AND WALTER OCHS
}

\section{INTRODUCTION}

Arid-land fluvial systems are regulated and delineated for Federal jurisdiction based on the concept of "Waters of the United States" (WoUS). The identification of WoUS in the field is performed using field indicators or Ordinary High Water Marks (OHWM) under the Clean Water Act (33 U.S.C. 1344). The concept of Ordinary High Water (OHW), defined in 33 CFR Part 328.3, was originally employed to delineate the extent of tidal and navigable waters. This concept has been carried forward to include non-tidal waters and is identified by the line on the shore established by the fluctuations of water as indicated by physical characteristics such as a clear, natural line impressed on the bank, shelving, changes in the character of the soil, the destruction of terrestrial vegetation, or the presence of litter and debris. In stream channels, including those in arid regions, the OHW boundary is determined by examining recent physical evidence of surface flow. The definition of OHW is based on physical evidence and lacks any statements concerning the duration and frequency of events.

Stream channels in arid regions differ in several ways from stream channels in more mesic regions of the country and from most navigable waters. In the arid West, channel morphology and, as a consequence, the physical features associated with OHWM are frequently the result of extreme floods or short-term, highintensity events (Graf 1988, Tooth 2000). These seasonal and cyclic climatic events, coupled with intense storm patterns, do not fit well within the wetland hydrology criteria of 1 out of 2 years, 5 out of 10 years, or $50 \%$ probability of occurrence for more than $5 \%$ of the growing season (Environmental Laboratory 1987, Office of the Chief of Engineers 1992). With its cyclic climatic patterns, 
the arid West can lack rainfall events for extended periods of time; however, when they do occur, they tend to be intense. These unevenly distributed and sometimes extreme precipitation and discharge patterns are in contrast to the more evenly distributed discharges associated with humid regions, such as the eastern U.S. Also, the ultimate timing and magnitude of runoff into arid streams has many controlling factors that contrast with the discharge rates and patterns of streams in more humid areas. Some of the factors important for understanding differences in runoff characteristics between arid and humid climates include the spatial and temporal variability of rainfall, interception, evaporation and transpiration, channel transmission losses, and the time to the onset of runoff after rainfall begins (Pilgrim et al. 1988, Niemczynowicz 1990, Nouh 1990).

OHWM indicators, originally intended to define the limits of OHW in tidal and navigable waters, are confounded by the drastic differences in the climate, geology, soil, and vegetation characteristics in which arid streams operate. Typically, the OHW limits when applied to perennial streams have been associated with the bankfull discharge (Rosgen 1996) and have been shown to have an average recurrence interval of 1.5 years (Dunne and Leopold 1978, Rosgen 1996). This average recurrence interval is commonly associated with perennially flowing stream channels where precipitation is evenly distributed. In contrast, arid stream channels have flashy and intense events associated with less evenly distributed precipitation events (Graf 1988). To understand the distribution of OHWM features and their reliability for identifying the OHW boundaries in arid western channels, our study analyzed their spatial arrangement in comparison to 2-, 5-, 10-, 15-, 25-, 50- and 100-year return interval discharges for test channels in the Mojave Desert. By modeling stream flood flow dynamics at set return intervals, we expected a correlation between OHWM features and certain flood return intervals as a way to help define the boundary of OHW in a seemingly chaotic system. 


\section{STUDY AREA}

Multiple test reaches were chosen to represent streams in various landscape positions, stream orders, and watershed morphologies. In addition, long-term (>30 years) continuous gauging records and minimal anthropogenic influences were required of each watershed to minimize the influence of any recent perturbations within the study reach. In this paper we focus on one study reach, Mission Creek (Fig. 1), which is located in the Mojave Desert near Desert Hot Springs, California. Mission Creek has a drainage area of 92.5 sq. km (35.7 sq. mi.) upstream from a USGS-operated gage, and characteristically steep mountains border its lateral margins. The study reach extends $1.15 \mathrm{~km}$ upstream from the gage, which is near the transition from a confined channel onto a broad alluvial apron, where thick sand and gravel sequences eroded from the surrounding mountains have been deposited.

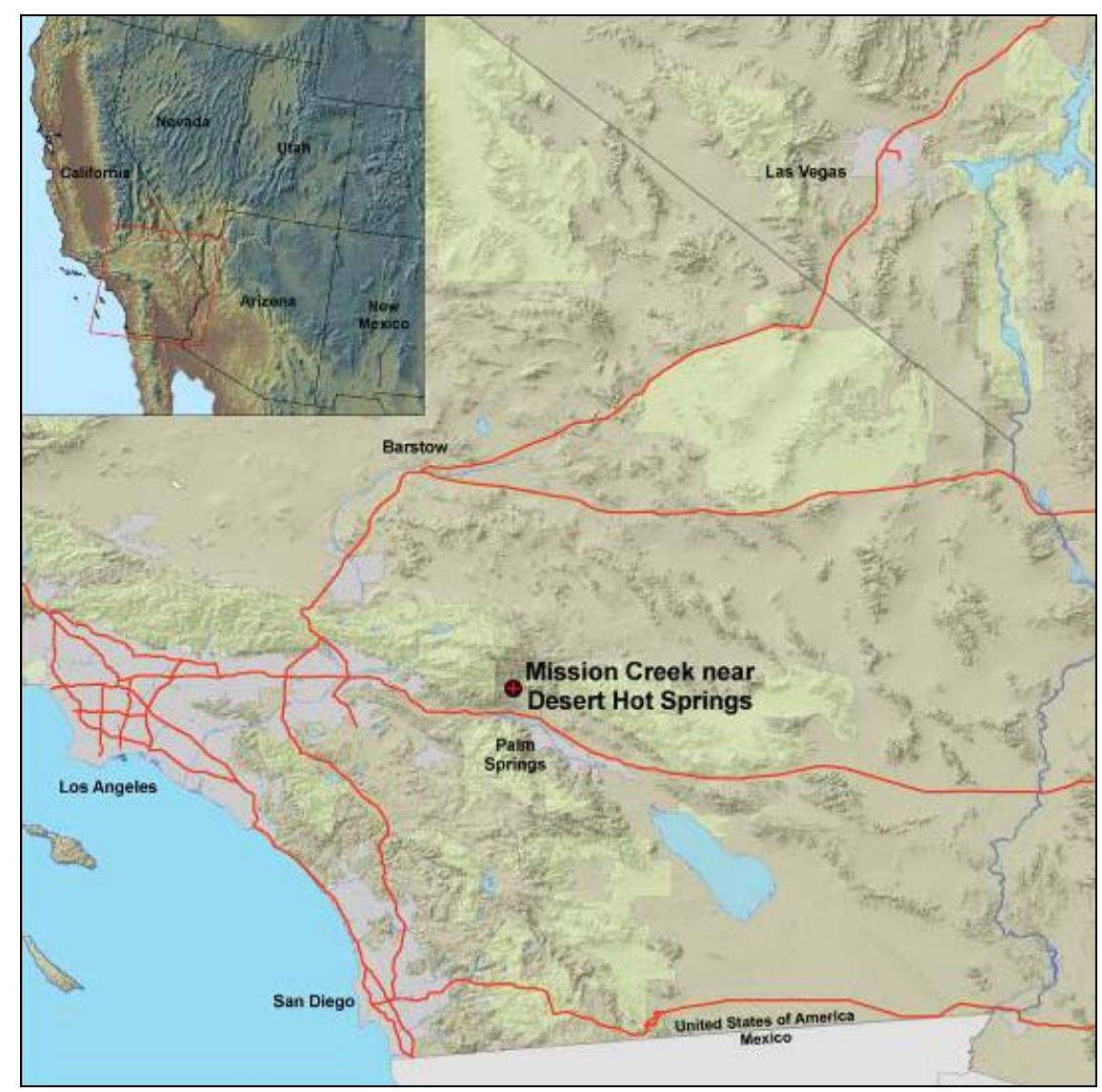

Figure 1. Location of the Mission Creek study site. 


\section{APPROACH/METHODS}

This research focuses on developing a method to accurately reproduce predetermined flood return inundation levels to support the field identification of physical features within the channel that best define the events associated with delineated boundaries of "Waters of the United States." By combining detailed field mapping information about OHW, vegetation, and other known parameters with high-resolution topographic data acquired from airborne laser altimetry (LiDAR) to support 1-D hydraulic modeling programs such as HEC-RAS, low-, intermediate-, and high-magnitude flow event inundation extents were reproducible. This combined field and technical approach highlights the potential utility of geomorphic signatures in establishing the extent of flood events representing OHW.

\section{Field Surveys}

Detailed mapping surveys were completed at each site using a custom, fieldbased GIS mapping application on pen-tablet computers using sub-meterresolution GPS and high-resolution color aerial photographs acquired using LiDAR. This effort provided the characterization and spatial distribution of potential OHWM indicators defined by Lichvar and Wakeley (2004) and from survey questionnaire responses solicited from western U.S. Army Corps of Engineer Districts. In addition to OHWM indicators mapped with a GPS in the field, a detailed vegetation inventory was collected by strata describing species, growth form, dominants, and percent cover. Hydrogeomorphic floodplain units were mapped and described as bankfull, active floodplain, or terrace floodplain, and the distribution of surficial grain size (or texture) was determined within each unit. This additional vegetative and geomorphic information was used to aid in estimating channel roughness and ultimately was incorporated into HEC-RAS hydraulic models.

\section{LiDAR Data}

Through a collaborative effort between CRREL and NASA's Airborne Topographic Mapper group based out of Wallops Island Flight Facility, Virginia, ATM-III LiDAR data were acquired over each of the candidate study sites in late September 2003. The ATM-III uses a blue-green laser to calculate a returned spatial vector from the platform to the point of reflection, providing an extremely precise XYZ coordinate of the laser footprint on the ground. These surveys were flown using a Twin Otter International twin-engine light aircraft, equipped with 
the ATM-III instrument, flown at an altitude of approximately $1500 \mathrm{~m}$ (Fig. 2). The ATM measures the surface topography to a precision of approximately $5 \mathrm{~cm}$ vertically and $100 \mathrm{~cm}$ horizontally (Krabill and Martin 1987). Following airborne acquisition, the raw data were reduced to essential components, projected to a UTM projection, filtered for atmospheric triggers and redundant data points, and binned into a final 1-m Digital Elevation Model using software developed inhouse with Research Systems Interactive Data Language (IDL) (Fig. 3).

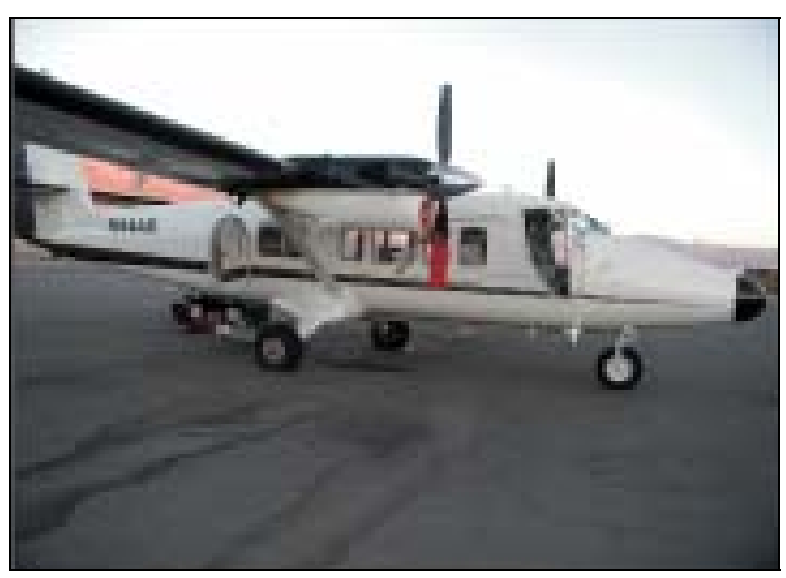

a. Twin Otter aircraft.

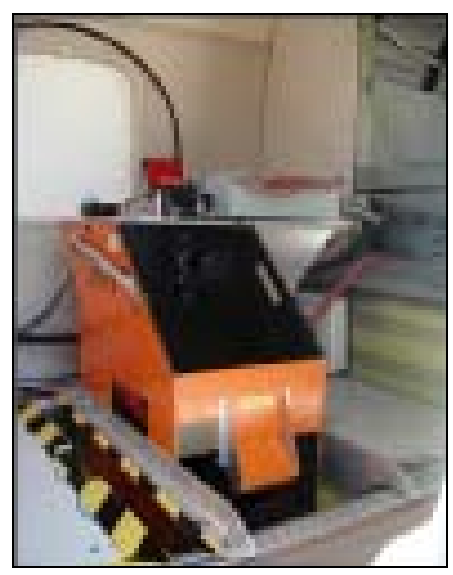

b. ATM-III instrument mounted and calibrated within the aircraft.

Figure 2. Aircraft and equipment used in acquisition of the LiDAR data.

\section{Flood Frequency Analysis}

Annual peak flood frequency analysis (FFA) was performed in accordance with Bulletin 17B Guidelines (Interagency Advisory Committee on Water Data 1982) using HEC-FFA software (Fig. 4). Peak flow, daily average discharge, and gage height values have been recorded since 1968, and 15-minute discharge and gage height values have been recorded since 1989. Peak flow values, using a skew coefficient of 0.1 , were determined from the generalized skew coefficient map in Bulletin 17B Guidelines to determine the magnitudes of floods with annual recurrence intervals of 2, 5, 10, 25, 50, and 100 years. The discharge value determined for each recurrence interval was used to calculate the stage at the gage based on the rating curve provided (Rantz et al. 1982). This stage was then used as the downstream boundary condition for the hydraulic models. 


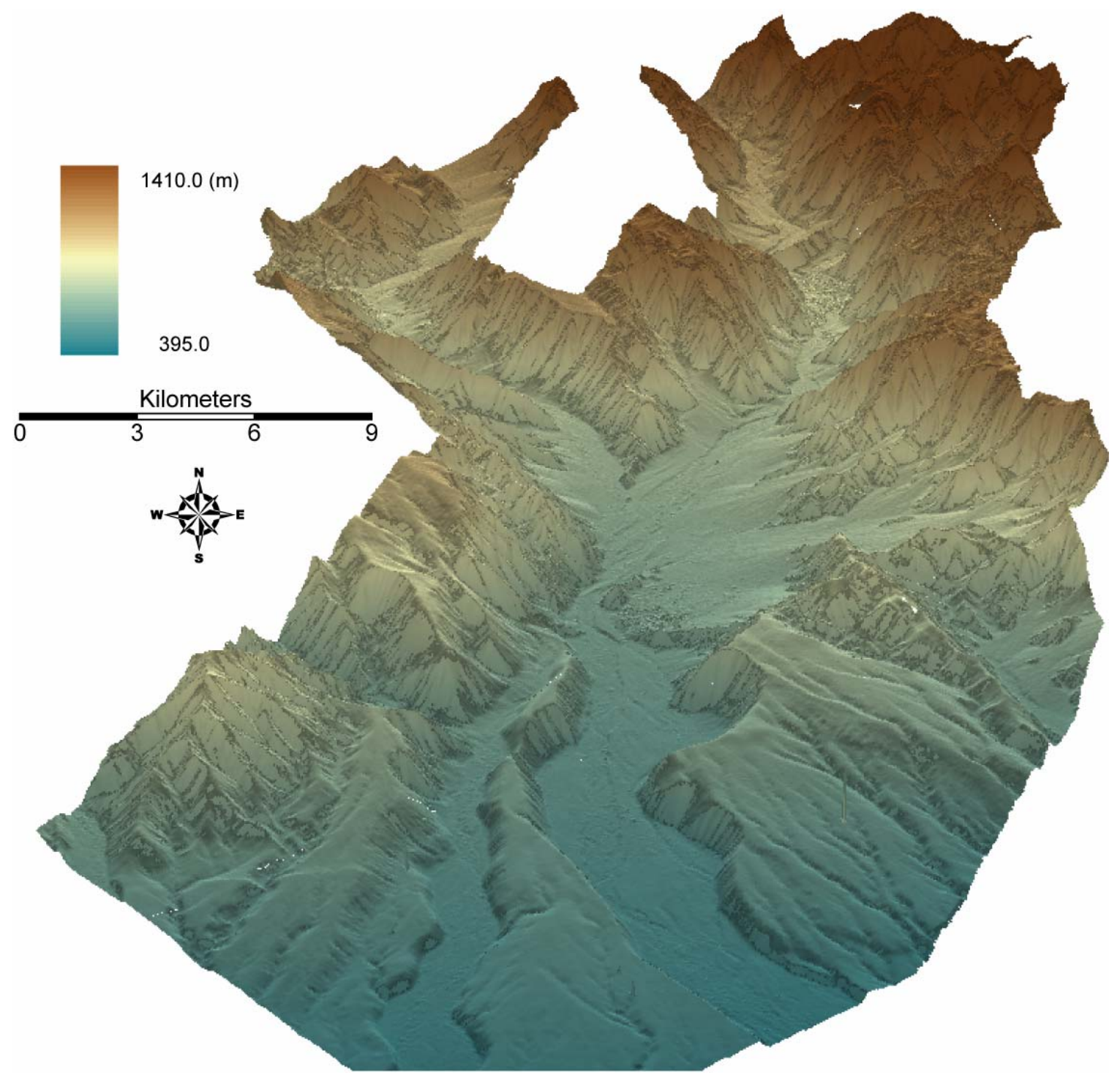

Figure 3. ATM-III LiDAR-derived Digital Elevation Model for Mission Creek, southern California. Elevation values are color-shaded for visual representation. Vertical exaggeration 1.5x. 


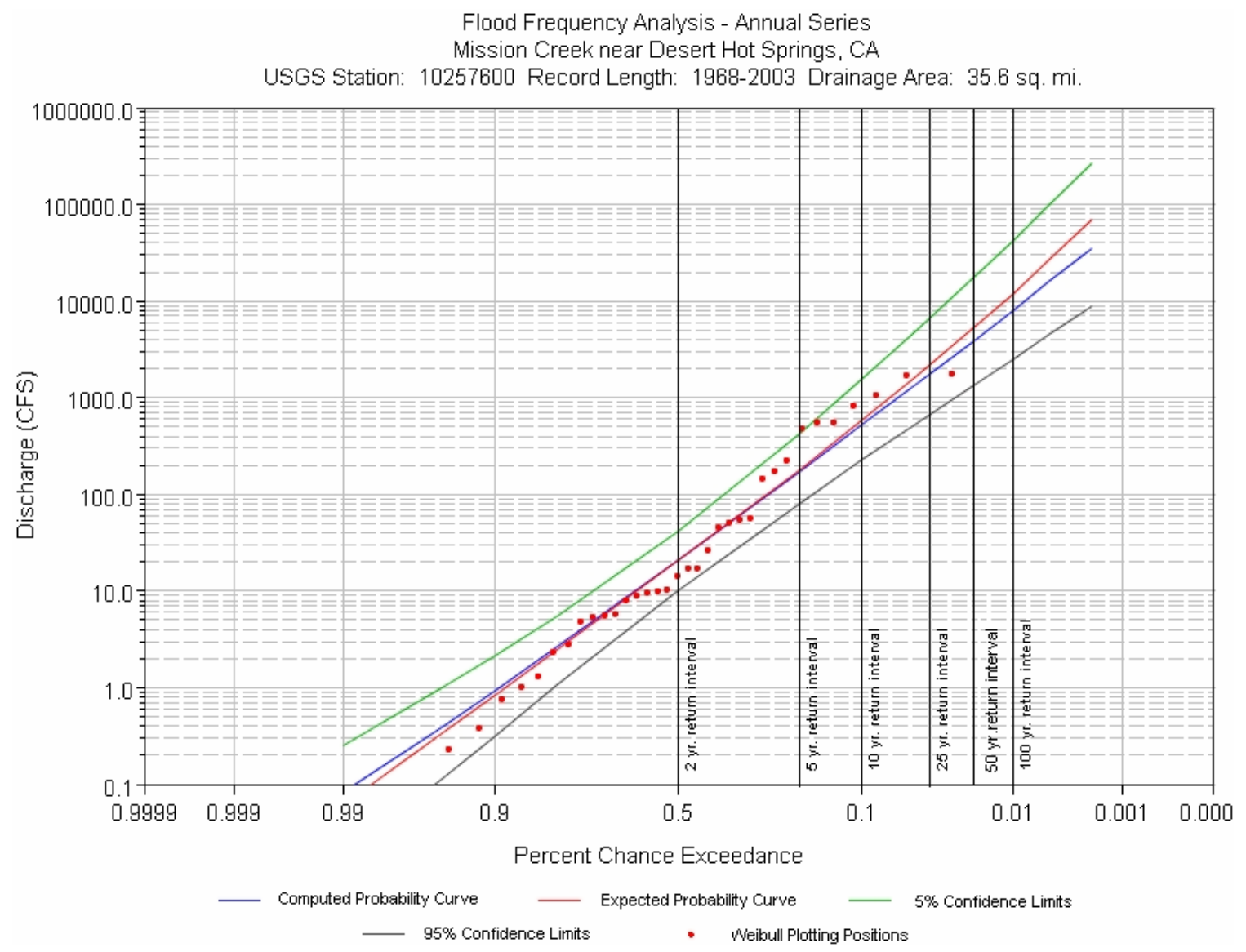

Figure 4. Estimated frequency of maximum annual discharges at the Mission Creek Gage.

\section{HEC-RAS 1-D Hydraulic Models}

Flood inundation models were generated using a HEC-RAS steady flow simulation for each predetermined flood return interval obtained from the gage data and the FFA. HEC-RAS is dependent on geometric, hydraulic, and hydrologic data inputs (U.S. Army Corp of Engineers 2002).

For each predetermined flood return interval discharge calculated using the gaging record within the FFA, a hydraulic flow model was generated using HECRAS. Geometric data consist of the cross-sectional geometry determined at prescribed intervals along a study reach. Our approach utilizes cross-sectional geometry derived from the NASA ATM LiDAR topographic data (Fig. 3). Individual channel cross sections were extracted at 2-m intervals along the channel center line. Other geometric parameters, such as bank stations, flow paths, and channel roughness, were extracted from the field mapping data. Channel rough- 
ness was determined using the environmental variables collected during field mapping. Surficial texture and vegetative growth form by strata were used to calculate a roughness height, which was used to determine a Manning's roughness value, which in turn was integrated into the model. No cross sections were interpolated. Flood inundation and velocity grids were generated using HEC-GeoRAS (U.S. Army Corp of Engineers 2005) to provide a detailed representation of the spatial extent and depth of water for each predetermined flood return discharge.

\section{Statistical Approach}

The distribution and location of OHWM indicators within the floodplain were analyzed for comparison with modeled flow events. Indicators within $1 \mathrm{~m}$ of the flood inundation boundary were considered within the inundation limits of the respective recurrence interval to better represent potential edge/boundary OHW indicators. Seven areas were defined: six areas were determined by the flood outlines of the 2-, 5-, 10-, 25-, 50-, 100-year recurrence interval floods, and the seventh area was outside the 100-year floodplain. These seven areas were used to associate a mean flood return interval and variability with each OHWM indicator type. Additionally, indicator density plots were used to analyze the density of each indicator type mapped within the extent of all return interval discharges.

The vegetative inventory and hydrogeomorphic characteristics were tabulated according to the percentage area occurring within the limits of each return interval discharge and analyzed using a nonparametric correlation method (Spearman's) to identify the floodplain characteristics that correspond with increasing flood frequency. All statistical analysis was accomplished using SigmaStat software (SYSTAT 2004). 


\section{$4 \quad$ RESULTS}

For comparative purposes, the fluvial surface morphologies and vegetative features (Fig. 5) within the test reach were mapped and divided into bankfull, active floodplain, and terrace floodplain hydrogeomorphic units. This fluvial classification, which follows descriptions in the literature but not exclusively for arid stream channels, allowed for analysis of data and OHWM indicator distribution patterns. The bankfull surface was identified by bed and bank features resulting from frequent discharges (Riggs 1985) that correlate to specific recurrence intervals from 1.4 to 1.6 years (Leopold et al. 1964, Rosgen 1996).

Adjacent to the bankfull channel, the active floodplain receives frequent overbank flow (Williams 1978, Province of British Columbia 1995, Rosgen 1996) representing a 2- to 10-year recurrence interval (Riggs 1985) and is characterized by high flow channels, generally unvegetated surfaces, and a break in slope. The terrace floodplain represents an abandoned alluvial feature formed during historic hydraulic conditions. The terrace will occasionally flood as a result of the shortterm heavy and long-term moderate rainfall patterns found in the Southwest (Graf 1988, Osterkamp and Friedman 2000. These events will typically activate paleo-channels and pond water in localized depressions found throughout the terrace; this infrequent flooding allows mature vegetation stands to become established.

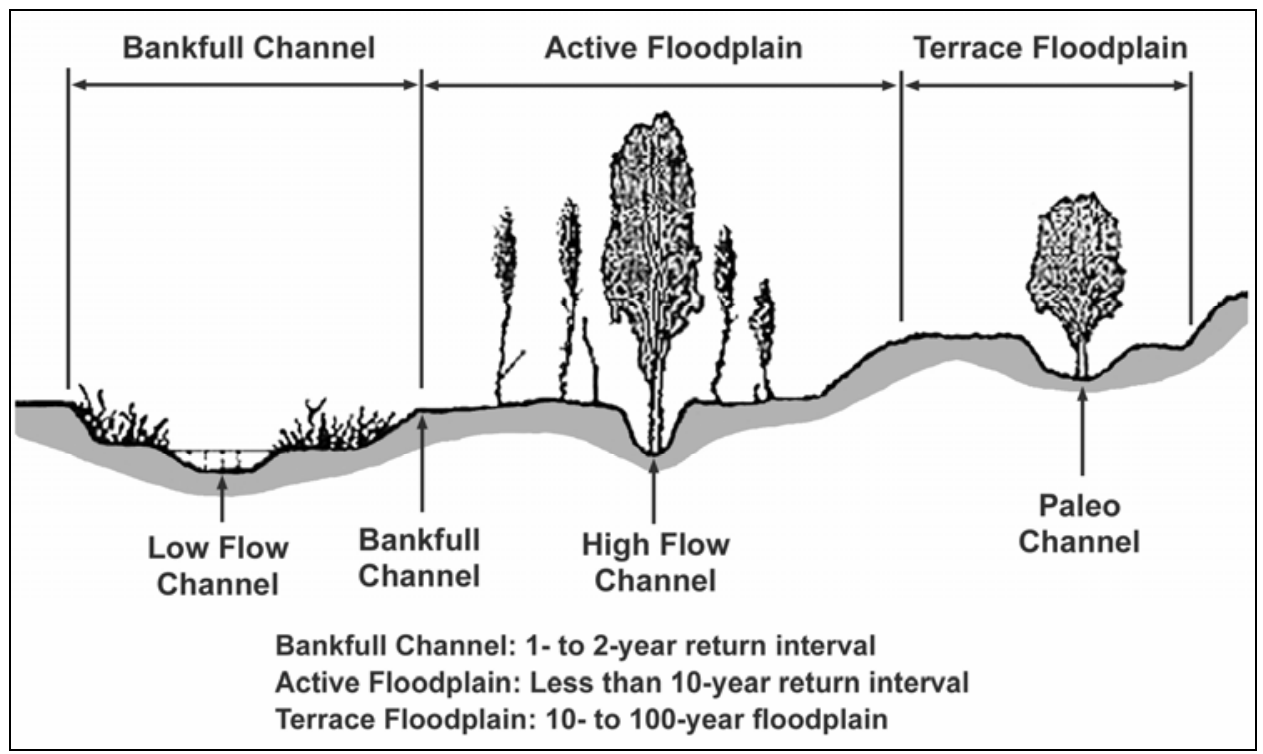

Figure 5. Typical arid southwestern stream cross section and its associated hydrogeomorphic floodplain units. (Adapted from Lichvar et al. 2004.) 
The complex topography within the test reach includes numerous channel braids and avulsions, abandoned terraces, and topographic lows that may be disconnected from the primary channel. This topography requires a unique and accurate approach to obtaining the hydrologic boundary conditions necessary for modeling each distinct flow event and evaluating OHWM indicator distributions. For this reason we used NASA ATM-III LiDAR-derived topography as the baseline for all modeled output. By integrating high-precision topography (approximately $5 \mathrm{~cm}$ vertical and $1 \mathrm{~m}$ horizontal), we were able to derive spatial outputs from HEC-RAS, such as inundation extent and depth, that were similar to the detailed mapping results obtained in the field (Fig. 6). By integrating modeled inundation and flow depth with the mapping results of the fluvial surfaces, other environmental variables, and point data for OHWM indicators, we observed several geomorphic and vegetative distribution patterns within the test reach (Fig. 7).

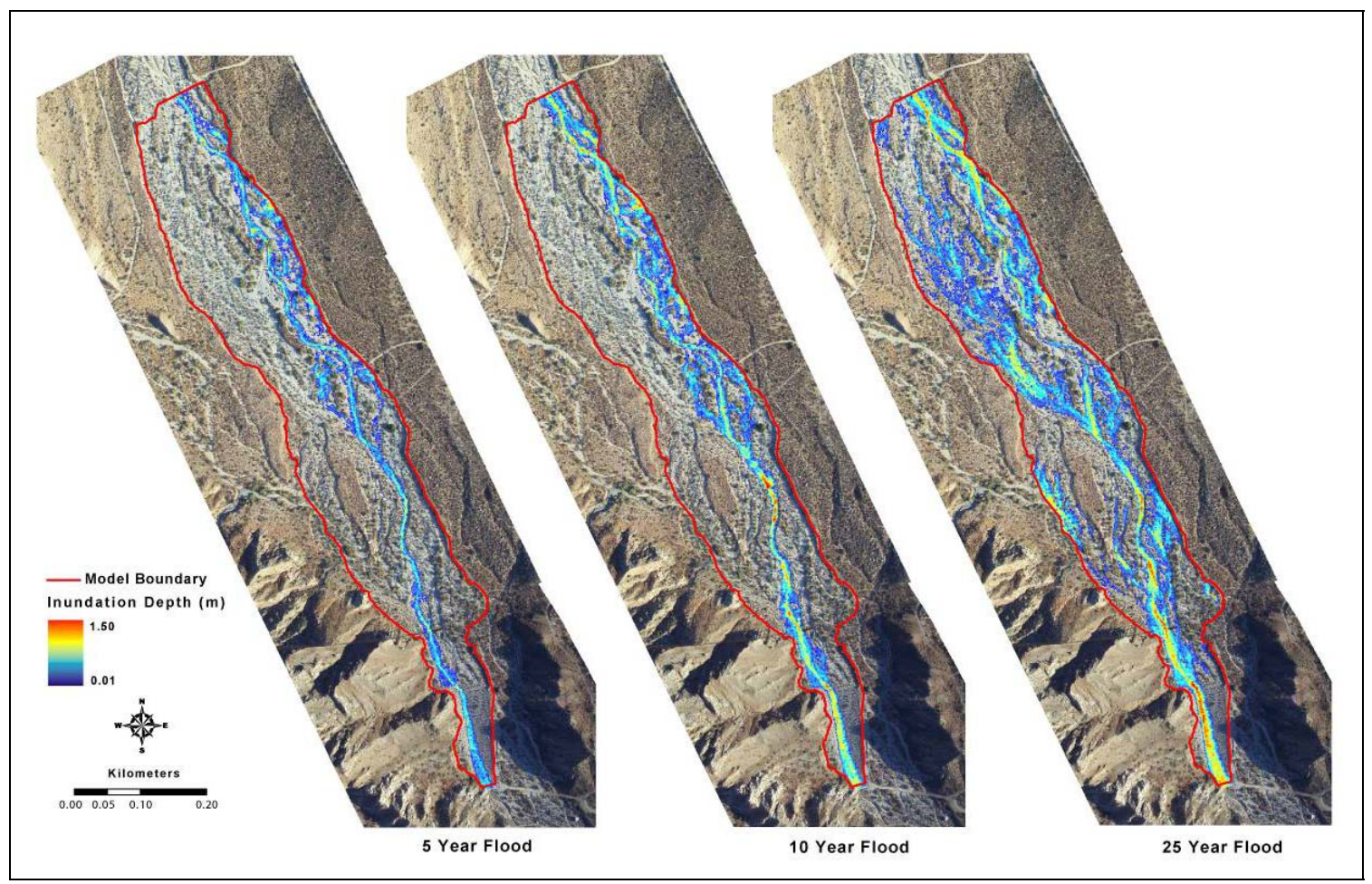

Figure 6. Select HEC-RAS modeling results for 5-, 10-, and 25-year calculated return interval discharges at Mission Creek. Modeling results were calculated using 2003 LiDARderived topography. 


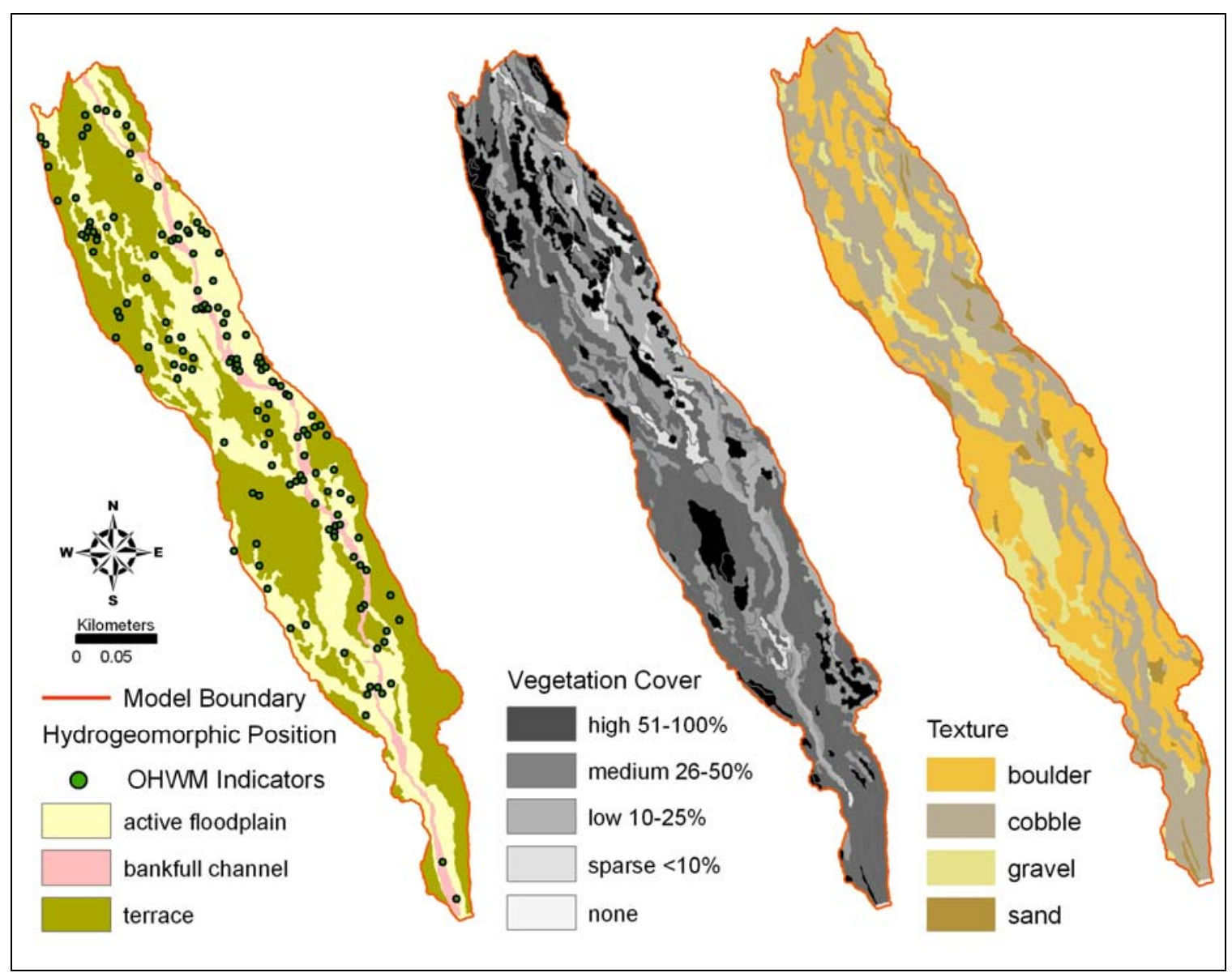

Figure 7. Field mapping results at Mission Creek for hydrogeomorphic positions and OHWM indicators (left), percent vegetation cover (middle), and composite geomorphic textures (right).

Two soil texture classes dominate the active floodplain and terrace. The texture classes of cobble and boulder were significantly distributed within a set gradient across the floodplain and terrace, respectively (Figure 7, right). The percent cobble, commonly associated with the most active part of the floodplain, decreased away from the active channel across the floodplain as the return interval increased and percent boulder increased. Similarly, the percent vegetation cover is lowest in most active parts of the floodplain associated with more frequent flood return intervals and increased on the terrace with greater magnitude floods. The number of vegetated strata also increased along with the overall plant cover in the floodplain areas with higher return intervals of flood events. The vegetation cover increase and cobble texture decrease are depicted in Figure 8. 


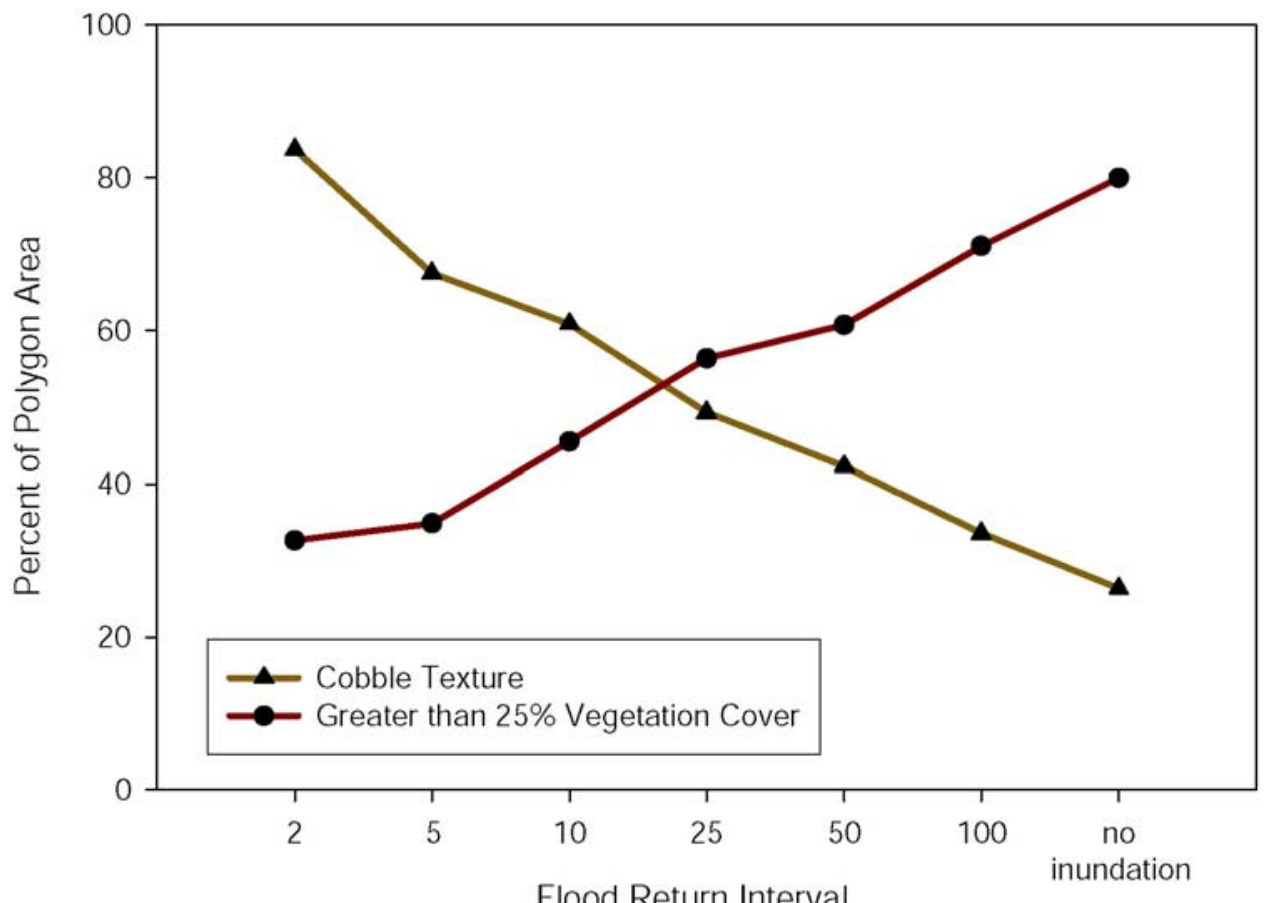

Figure 8. Vegetation and cobble textures correlated to flood return intervals and mapped polygon areas. Vegetation cover over $25 \%$ was significantly correlated with infrequent events $\left(r_{s}=1.000, p<0.0001\right)$, and cobble texture was significantly correlated with increasing flood frequency $\left(r_{s}=1.000, p<\right.$ 0.0001).

Of the 14 potential OHWM indicators identified by Lichvar and Wakeley (2004), only six were present at Mission Creek. Of those OHWM indicators present, 74\% were located in the active floodplain and bankfull channel and included drift, mud cracks, small silt deposits, and knick points. Descriptions of all six OHWM indicators are presented in Table 1. In general, the majority of the OHWM indicators present were spread across the entire floodplain and not associated with any specific events (Fig. 9). Two of the indicators, knick points and silt deposits, were more limited to specific event levels. Knick points were located along the bankfull channel, and the silt deposits were higher on the landscape. 


\begin{tabular}{|lcl|}
\hline & \multicolumn{2}{c|}{ Table 1. OHWM indicators, Mission Creek 2003. } \\
\hline $\begin{array}{c}\text { OHWM } \\
\text { indicators }\end{array}$ & $\begin{array}{c}\text { Number of } \\
\text { occurrences }\end{array}$ & \multicolumn{1}{c|}{ Brief description } \\
\hline Drift & 104 & Organic debris oriented to flow direction(s) (larger than small twigs) \\
Mud cracks & 6 & Desiccation cracks within silt deposits \\
Silt deposits & 8 & Silt found in micro-depressions \\
Sand deposits & 17 & Sand oriented downstream to flow direction(s) \\
Knick points & 4 & Abrupt change in channel slope \\
Litter & 17 & Organic debris oriented to flow direction(s) (small twigs and leaves) \\
\hline
\end{tabular}
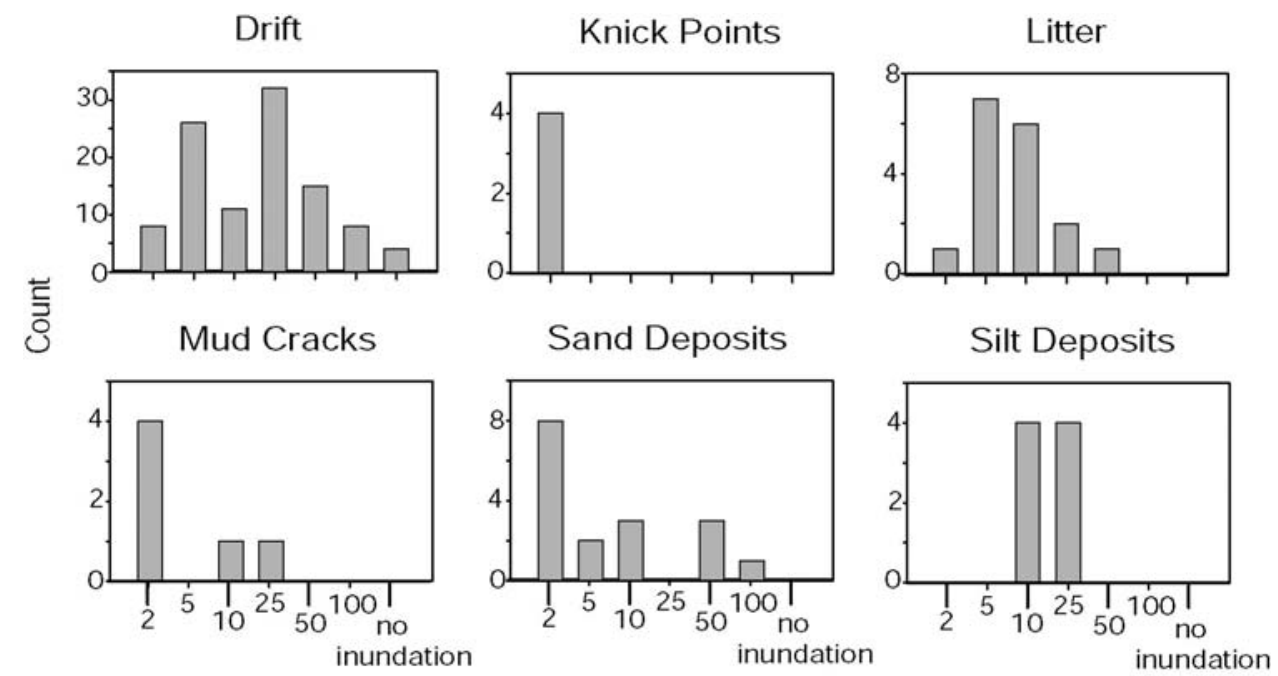

Flood Return Interval

Figure 9. OHWM indicators collected at Mission Creek and their distribution within the flood return intervals. 


\section{DISCUSSION}

In the field, the COE and other Federal and state agencies perform delineations of the OHW extent in arid western channels. These determinations rely on the physical evidence and locations of OHWM indicators. In some instances, various delineators determine the extent of the OHW location to be at different locations in the channel. The initial results from our data may help explain how these differences in the field are occurring based on the overall response of the channel to a combination of flood events.

The location and identification of the bankfull channel, active floodplain, and abandoned terraces are reasonably well explained and documented for perennial streams (Leopold et al. 1964, Rosgen 1996). In these systems, many of the OHWM indicators are located in channel positions that represent frequently occurring events near the bankfull channel (Rosgen 1996). In arid southwestern channels, however, the physical evidence associated with $\mathrm{OHW}$ is frequently the result of moderate to extreme flood events (Graf 1988, Tooth 2000). The shape of the bankfull channel, as well as other aspects of the floodplain such as the channel's cross-sectional shape and gradient, is adjusted to prevailing watershed conditions that control the amount of sediment and water delivered to the channel (Leopold 1964, Leopold and Bull 1979). With dominant, or effective, discharge in the arid west being "flashy”(intermittent and extreme), the overall response of the channel reflects these conditions (Tooth 2000). Likewise, the distribution of OHWM indicators follows a similar response to these regional conditions.

There appears to be no direct correlation between the location of OHWM indicators and the inundation areas associated with specific recurrence interval flood events. The location of OHWM indicators seems to have two patterns: 1) $74 \%$ of the indicators are located within the bankfull and active floodplain channels and 2) the indicators are not associated with any return interval event or with physical channel features found in the field. This response of OHWM indicators may be more typical of the arid West than the perennial stream channels of the East.

The hydrograph for the last 16 years at Mission Creek shows a series of lowto moderate-discharge flood events bounded by more extreme events (Fig. 10). The more frequent events have return intervals of less than 5 years, while the more extreme events have return intervals of 5-10 years. Modeled outputs corresponding to the more extreme events correlate well with the outer limit of the active floodplain, and the more frequent events correspond with the bankfull channel (Fig. 6). Using flood models, we have been able to correlate hydro- 


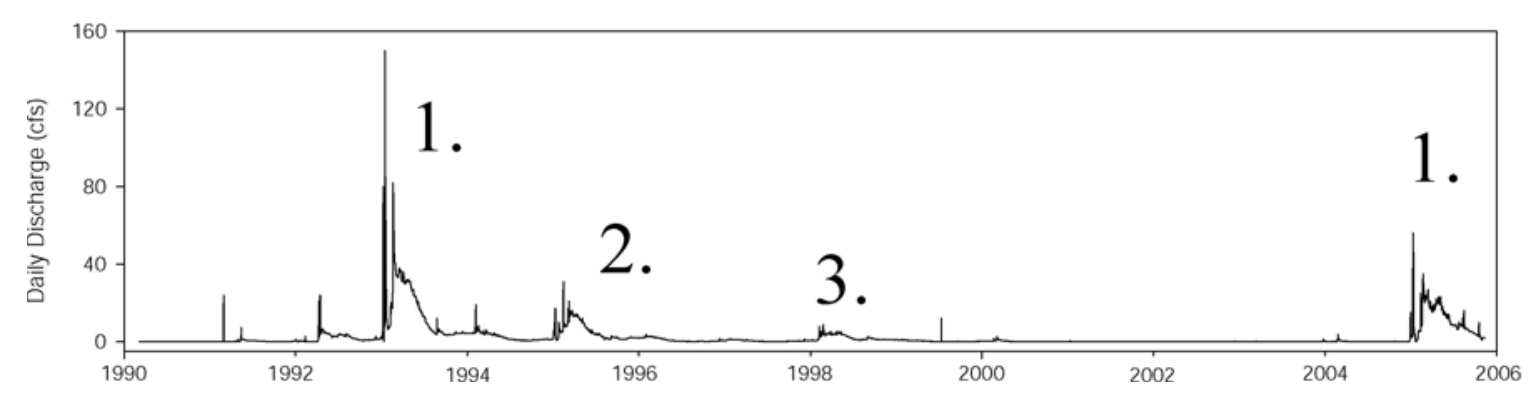

Figure 10. Observed flood hydrograph for Mission Creek.

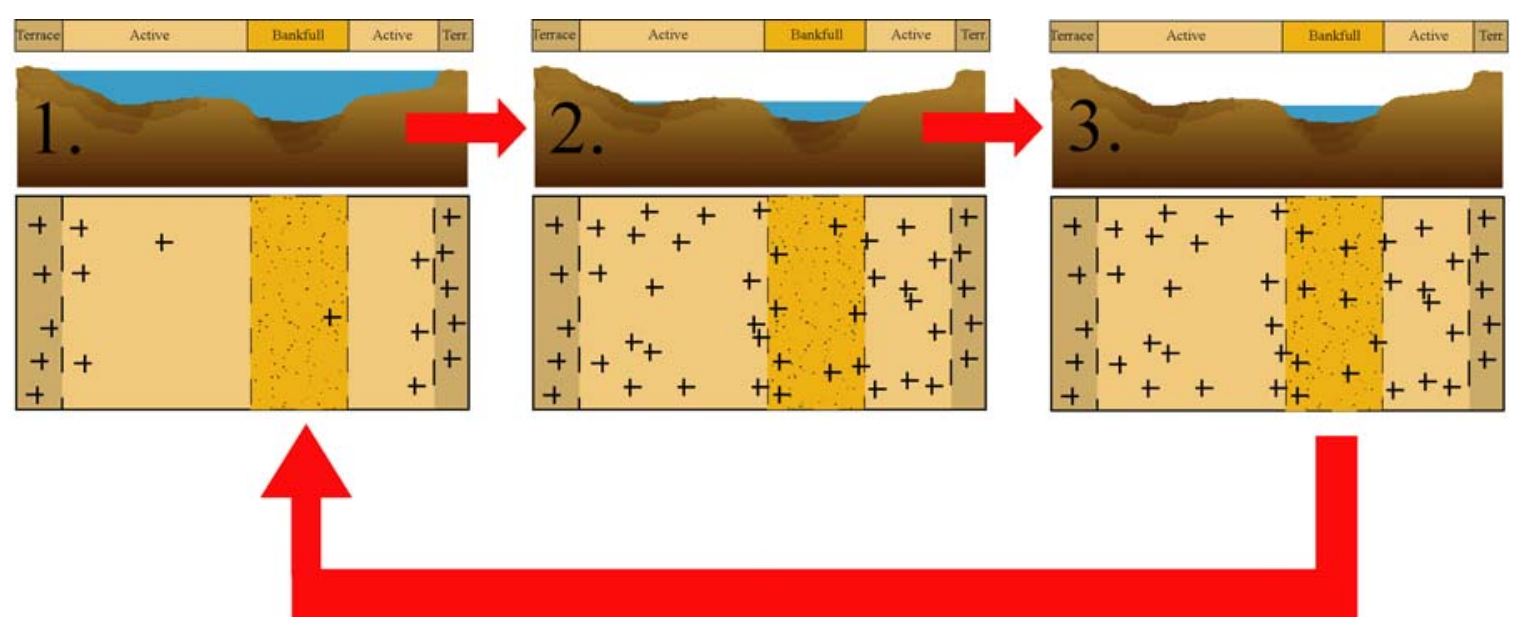

Figure 11. Working OHW concept model for understanding the distribution of OHWM indicators. (The crosses represent various indicators, see Table 1; The numbers correspond to the events shown in Fig. 10.)

geomorphic channel features to a repeating series of flood events, but these events do not correlate to the return intervals published in the literature for bankfull and active (Province of British Columbia 1995, Rosgen 1996). Even with a correlation between field-derived channel surface features to return interval flow events, the placement of OHWM indicators still did not correspond well with any repeating discharge level.

To explain the random distribution pattern of OHWM indicators across the channel, we have developed a new working hypothesis. The concept of this model is driven by several results discovered during this initial study. The major contributions driving this concept are the high-magnitude, short-duration (or "flashy") discharge events; the alignment of the active floodplain boundary to the 
5- to 10-year return interval; and the random locations of OHWM indicators throughout the channel. We propose that in arid western channels where discharges are "flashy," a pattern of varying discharges is responsible for the apparent random distribution of OHW indicators. During moderate, 5- to 10- year events (Fig. 11, event 1), abundant work is done by reworking channel and floodplain sediments, removing vegetation, and establishing a new hydraulic geometry within the affected area. The extent of this moderate event forms the limit of the current active floodplain. Any OHW indicators deposited within the active floodplain prior to the event are removed, and new OHWM indicators are deposited as the water recedes. Subsequent smaller-discharge, 1- to 3-year events (Fig. 11, events 2, 3), primarily confined within the active and bankfull channels, are effective in replacing OHW indicators within the limits of the active floodplain over time. This replacement of indicators continues until another moderate or larger event with sufficient competence completes the cycle by again removing all OHW indicators within the active floodplain. Working within this cyclical concept, the limits of the active floodplain remain the sole feature that is repeatable over time and at any discrete point in time within the cycle. The bankfull boundary in the arid West is frequently mobilized and changes location during moderate or larger events and is not as reliable as in the humid East in identifying the OHW. This removal of previous OHWM indicators and establishing of a new time sequence may help explain why various wetland delineators determine the placement of the OHW boundary at different locations. This repeating series of moderate events represents the repeatable limits of "ordinary" discharges for arid western channels.

This concept of moderate events representing the "ordinary" discharge in arid channels re-influences our interpretation of the location of the OHW boundary. Since the active floodplain in dry washes performs the same functions as the bankfull channel within a perennial stream, where the majority of hydrological and fluvial work is occurring, and has the majority of water flowing through it to provide the greatest wetland function, we are proposing a method to delineate the active floodplain. The extent of the active floodplain is the only repeatable feature within the floodplain and is recognized by sparse vegetation cover and an increasingly sandy to cobble-textured surface. These are readily observable on aerial photography from Mission Creek and other arid western stream channels and can be located in the field (Fig. 11). 

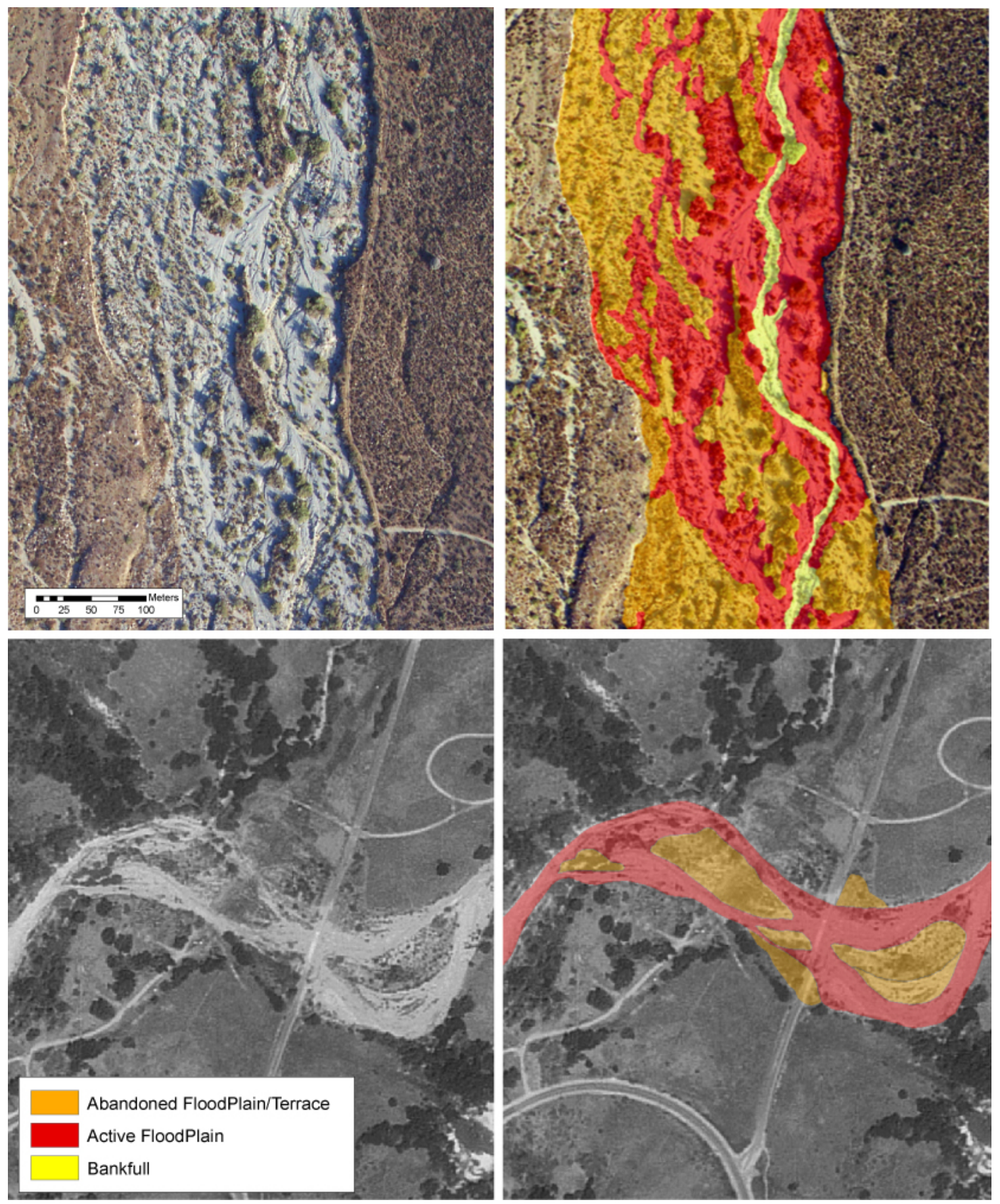

Figure 11. Aerial photography and field-derived channel boundaries showing the active floodplain identified by the reduced vegetation cover and sandy to cobble textures. Top: Mission Creek, near Desert Hot Springs, CA; Bottom: San Juan Creek, San Juan Capistrano, CA. 
Continuing research will focus on contrasting the high-discharge events encountered during the winter of 2004-2005 to the new model concept and developing a delineation technique. In September 2005, NASA ATM-IV LiDAR was acquired again at all test reaches used in this study, in addition to follow-up detailed field mapping. These new datasets will be used to model known flood events, generate a geomorphic change detection between these events to look for unique geomorphic fingerprints of each event, and test our "ordinary channel" concept, which in the case of arid southwestern channels we've determined is the entire active floodplain. Using the same datasets, we will develop the use of OHWM indicators associated with the active floodplain limits, photographic and field delineation techniques, and use of simple stream gage techniques to confirm the limits of OHW. 


\section{REFERENCES}

Dunne, T., and L.B. Leopold. 1978. Water in environmental planning. San Francisco, CA: W.H. Freeman.

Environmental Laboratory. 1987. Corps of Engineers wetlands delineation manual. Technical Report Y-87-1. Vicksburg, MS: U.S. Army Environmental Laboratory.

Graf, W.L. 1988. Definition of flood plains along arid-region rivers. In Flood geomorphology, ed. V. Baker, R.C. Kockel, and P.C. Patton. New York: John Wiley and Sons.

Interagency Advisory Committee on Water Data. 1982. Guidelines for determining flood flow frequency. Bulletin 17B. Reston, VA: Hydrology Subcommittee, Office of Water Data Coordination, U.S. Geological Survey.

Krabill, W., and C.F. Martin. 1987. Aircraft positioning using global positioning system carrier phase data. Navigation 34: 1-21.

Leopold, L., and W.B. Bull. 1979. Base level aggregation and grade. Proceedings of the American Philosophical Society 123: 168-202.

Leopold, L., M.G. Wolman, and J.P. Miller. 1964. Fluvial processes in geomorphology. San Francisco and London: W.H. Freeman and Co.

Lichvar, R.W., and J.S. Wakeley. 2004. Review of ordinary high water mark indicators for delineating arid streams in the southwestern United States. ERDC TR-04-1. Hanover, NH: U.S. Army Engineer Research and Development Center.

Niemczynowicz, J. 1990. Some examples of important problems connected to rainfall-runoff modelling in semi-arid zone. The State-of-the-Art of Hydrology and Hydrogeology in the Arid and Semi-arid Areas of Africa, Proceedings of the Sahel Forum, Ouagadougou, 1989, 255-266.

Nouh, M. 1990. Flood hydrograph estimation from arid catchment morphology. Hydrological Processes 4: 103-120.

Office of the Chief of Engineers. 1992. Clarification and interpretation of the 1987 manual. Memorandum for SEE Distribution, 6 March 1992, Washington, DC.

Osterkamp, W.R., and J.M. Friedman. 2000. The disparity between extreme rainfall events and rare floods, with emphasis on the semi-arid American West. Hydrological Processes 14: 2817-2829.

Pilgrim, D.H., T.G. Chapman, and D.G. Doran. 1988. Problems of rainfall-runoff modeling in arid and semiarid regions. Hydrology Sciences Journal 33: 379-400. 
Province of British Columbia. 1995. Riparian management area guidebook. http://www.for.gov.bc.ca/tasb/legsregs/fpc/fpcguide/riparian/rip-toc.htm, accessed March 2001.

Rantz, S.E., 1982. Measurement and computation of streamflow: Volume 2, Computation of discharge. Water-Supply Paper 2175. U.S. Geological Survey, 285-631.

Riggs, H.C. 1985. Streamflow characteristics. Amsterdam, The Netherlands, and New York, NY: Elsevier.

Rosgen, D. 1996. Applied river morphology. Pagosa Springs, CO: Wildland Hydrology.

SYSTAT. 2004. SigmaStat for Windows Version 3.01.0. Richmond, CA:

SYSTAT Software Inc.

Tooth, S. 2000. Process, form and change in dryland rivers: A review of recent research. Earth-Science Review 51: 67-107.

U.S. Army Corps of Engineers. 2002. HEC-RAS River Analysis System User's Manual. Davis, CA: Hydrologic Engineering Center.

U.S. Army Corps of Engineers. 2005. HEC-GeoRAS River GIS Tools for support of HEC-RAS using ArcGIS, CPD-83 User's Manual. Davis, CA: Hydrologic Engineering Center.

Williams, G.P. 1978. Bank-full discharges of rivers. Water Resources Research 14(6): 1141-1153. 


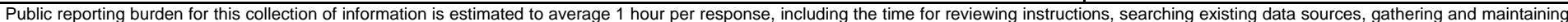

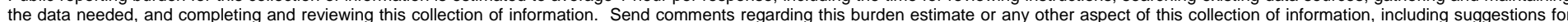

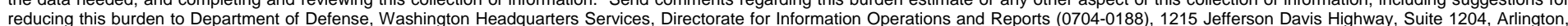

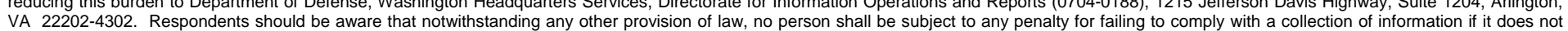
VA 22202-4302. Respondents should be aware that notwithstanding any other provision of law, no person shall be sube
display a currently valid OMB control number. PLEASE DO NOT RETURN YOUR FORM TO THE ABOVE ADDRESS.

\begin{tabular}{l|l} 
1. REPORT DATE (DD-MM-YYYY) & 2. REPORT TYPE \\
February 2006 & Technical Report \\
\hline
\end{tabular}

\section{TITLE AND SUBTITLE}

Distribution of Ordinary High Water Mark (OHWM) Indicators and Their Reliability in Identifying the Limits of "Waters of the United States" in Arid Southwestern Channels

\section{AUTHOR(S)}

Robert W. Lichvar, David C. Finnegan, Michael P. Ericsson, and Walter Ochs

\section{PERFORMING ORGANIZATION NAME(S) AND ADDRESS(ES)}

U.S. Army Engineer Research and Development Center

Cold Regions Research and Engineering Laboratory

72 Lyme Road

Hanover, NH 03755-1290

\section{SPONSORING I MONITORING AGENCY NAME(S) AND ADDRESS(ES)}

Office of the Chief of Engineers

Washington, D.C. 20314-1000

\section{DATES COVERED (From - To)}

5a. CONTRACT NUMBER

5b. GRANT NUMBER

5c. PROGRAM ELEMENT NUMBER

5d. PROJECT NUMBER

5e. TASK NUMBER

5f. WORK UNIT NUMBER

8. PERFORMING ORGANIZATION REPORT NUMBER

ERDC/CRREL TR-06-5

10. SPONSOR/MONITOR'S ACRONYM(S)

11. SPONSOR/MONITOR'S REPORT NUMBER(S)

\section{DISTRIBUTION I AVAILABILITY STATEMENT}

Approved for public release; distribution is unlimited.

Available from NTIS, Springfield, Virginia 22161.

13. SUPPLEMENTARY NOTES

\section{ABSTRACT}

The U.S. Army Corps of Engineers (COE) is actively involved in floodplain management and regulation of dry wash floodplains in the western United States. The COE also regulates "Waters of the United States" (WoUS) under Sec. 404 of the Clean Water Act by determining the extent of surface indicators related to “ordinary” flood discharges known as Ordinary High Water Marks (OHWM). The return interval for inundation to the WoUS boundary is not well understood in the arid West. COE hydrologic models require detailed site information for rainfall and stream flow characteristics, as well as on-site surveys to determine channel morphology, width, fluvial patterns, slope, and other physical attributes. The focus of this research is to quantitatively correlate field indicators to flood return inundation levels in support of identifying the events that best represent the extent of the "ordinary" high water using high-resolution topography acquired through Light Detection and Ranging (LiDAR). The NASA's Airborne Topographic Mapper (ATM) was the source of high-resolution topographic data for several stream reaches throughout the Mojave Desert, California. This research showed that field indicators commonly used to delineate the extent of the OHW are distributed across the entire floodplain and are not associated with a particular level of event. However, a consistent pattern of geomorphic signature and vegetation density is highly correlated to moderate flood events. A hypothesis and a working model were developed to explain the distribution pattern of various OHWM indicators and the repeating geomorphic signature.

\begin{tabular}{lll}
\hline 15. SUBJECT TERMS & Intermittent stream channels & Ordinary High Water Marks (OHWM) \\
Arid stream channels & LiDAR & OHWM indicators \\
HEC-RAS & Ordinary High Water
\end{tabular}

\begin{tabular}{ll|l} 
HEC-RAS & Ordinary High Water \\
\hline 16. SECURITY CLASSIFICATION OF: &
\end{tabular}

\begin{tabular}{|c|c|c|c|c|}
\hline \multicolumn{2}{|l|}{} & $\begin{array}{c}\text { 17. LIMITATION } \\
\text { OF ABSTRACT }\end{array}$ & $\begin{array}{l}\text { 18. NUMBER } \\
\text { OF PAGES }\end{array}$ \\
\cline { 1 - 2 } a. REPORT & b. ABSTRACT & c. THIS PAGE & & \\
& $\mathrm{U}$ & $\mathrm{U}$ & $\mathrm{U}$ & 29 \\
\hline
\end{tabular}

\section{9a. NAME OF RESPONSIBLE} PERSON

19b. TELEPHONE NUMBER (include area code) 